\title{
Mesozoic magmatism in the Falkland Islands (South Atlantic) and their offshore sedimentary basins
}

\author{
P C. RICHARDS $*^{1}$, P. STONE ${ }^{1}$, G. S. KIMBELL ${ }^{2}$, W. C. McINTOSH ${ }^{3}$ \& E. R. \\ PHILLIPS ${ }^{1}$
}

${ }^{1}$ British Geological Survey, Murchison House, West Mains Rd, Edinburgh, EH9 3LA, $U K$

${ }^{2}$ British Geological Survey, Keyworth, Nottingham, NG12 5GG, UK

${ }^{3}$ New Mexico Geochronological Research Laboratory, 801 Leroy Place, Socorro, NM 87801, USA

*Corresponding author,email: pcr@bgs.ac.uk

This Manuscript version of a paper submitted for publication in the Journal of Petroleum Geology-anticipated publication date January 2013 is presented here by kind permission of Blackwells. Please see www.jpg.co.uk for the final published article

Recent mineral and hydrocarbons exploration in and around the Falkland Islands has provided data that allows correlation of the onshore and offshore histories of magmatism. New Ar-Ar age dating of onshore dykes in East Falkland has extended their Cretaceous age range back to c. $135 \mathrm{Ma}$ (Valanginian-Hauterivian) from the previously reported age of ca $121 \mathrm{Ma}$ (Aptian). Widespread onshore, c.188-178 Ma, Jurassic dykes are generally considered a part of the regional Karoo-Ferrar magmatism linked to the initial break-up of Gondwana, but we relate the Early Cretaceous dykes, with their characteristic north-south orientation, to extension of the Falklands Plateau during initiation of spreading in the South Atlantic Ocean. The onshore dykes demonstrate east-west, Early Cretaceous extension, whilst to the north of the archipelago the offshore North Falklands Basin extended between north-south boundary fault systems from the Late Jurassic onwards. Intrusion of ValanginianHauterivian dykes onshore was penecontemporaneous with the intrusion of sills and the extrusion of lavas in the Falkland Plateau Basin. This magmatism, more extensive than previously supposed, may be linked to regional uplift associated with initial opening of the South Atlantic Ocean. The uplift can be demonstrated from seismic data and DSDP boreholes to have occurred during the Berriasian-Hauterivian interval. The thermally driven uplift of the platform region played a crucial role in elevating 
potential sediment source areas and providing the large volumes of sand that were shed intermittently into the surrounding basins from the Valanginian to Aptian or Albian.

\section{INTRODUCTION}

The Falkland Islands lie in the South Atlantic Ocean at the western end of the Falkland Plateau, a rectilinear, relatively shallow water ( $<2500 \mathrm{~m}$ approximately) bathymetric feature that extends eastwards from the South American continental shelf (Fig. 1a). Around the archipelago, Mesozoic (mid-Jurassic and later) sedimentary basins are currently the focus of offshore hydrocarbons exploration within the designated Falkland Islands Exploration Area (Fig. 1a). The North Falkland Basin has seen the greatest activity with 22 commercial boreholes: 6 drilled in 1998 (Richards and Hillier, 2000a and b), and 16 drilled in a single campaign from February 2010 until November 2011, encompassing five hydrocarbon discoveries: Liz - gas and gas condensate; Sea Lion - oil; Casper - gas and oil; Casper South - gas and oil; Beverley - gas (Fig. 2). The Sea Lion discovery was subjected to extensive appraisal drilling during 2011. The basin is structurally isolated within the Falkland Plateau to the north of the islands and comprises a complex of graben and half-graben sub-basins trending broadly north-south (Richards and Hillier, 2000a and b).

The Falkland Plateau Basin, with only three commercial boreholes to date (one in 2010 and two in 2012), lies to the south-east of the islands. A gas discovery (Loligo) was made during 2012 (Fig. 2) but detailed results are still commercially sensitive. The basin has a NE-SW-trending partially-faulted western margin and terminates eastward at the Maurice Ewing Bank, a bathymetric high some $750 \mathrm{~km}$ east of the Falkland Islands which was drilled by the Deep Sea Drilling Project (Barker \& Dalziel 1976).

To the west of the Falklands archipelago, the Malvinas Basin has been explored by about 20 commercial boreholes in Argentine waters and is linked with the Falkland Plateau Basin by the South Falkland Basin, a feature that trends east-west along the northern side of the Scotia - South America plate boundary, and plunges steeply to the south into the plate boundary fault zone: two wells, including a gas condensate discovery (Darwin), have been drilled in the South Falkland Basin during 2012 
(Figure 2), but detailed results are still commercially sensitive and unavailable for publication. A regional overview of the offshore sedimentary basins surrounding the Falkland Islands is provided by Richards et al. (1996).

Onshore, a clastic sedimentary sequence ranging in age from Siluro-Devonian to Permian makes up most of the Falkland Islands. Despite the proximity of the archipelago to South America, the regional geological association is with the Cape Province of South Africa, as has long been recognized (e.g. Andersson 1907; Halle 1911) and utilized by early proponents of continental drift (e.g. Baker 1924; Du Toit 1927, 1937). As in South Africa, the Falklands sedimentary succession is cut by numerous dolerite dykes. Until recently those in the Falklands were regarded as exclusively Jurassic (Mussett \& Taylor 1994), but they are now known to be both Jurassic and Cretaceous in age (Stone et al. 2008). Palaeomagnetic results from the Jurassic dykes (Taylor \& Shaw 1989) have been taken to support the proposition that the Falkland Islands form part of a microplate that during the break-up of Gondwana was rotated through $180^{\circ}$ from an original position adjacent to the east coast of South Africa (Adie 1952; Mitchell et al. 1986; Marshall 1994; Storey et al. 1999). Stone et al. (2009) subsequently demonstrated that the differing asymmetries of the magnetic anomalies associated with the various onshore dyke swarms are compatible with a $120^{\circ}$ rotation of the Islands sometime between $188 \mathrm{Ma}$ and $121 \mathrm{Ma}$.

In their 1996 paper, Richards et al. drew attention to the apparent discrepancy between the Early Cretaceous ages deduced for sills and/or lava flows detected in seismic sections from the Falkland Plateau Basin, and the Early Jurassic ages then thought to apply to all of the onshore Mesozoic dykes. Recent results have resolved this dilemma. Evidence for Early Cretaceous dyke intrusion onshore was presented by Stone et al. (2008) and in this paper we present new Ar-Ar dating results from the Cretaceous dyke swarm in East Falkland that support a revision of its age range, from the Aptian (c. $121 \mathrm{Ma}$ ) age reported by Stone et al. (2008), back to the ValanginianHauterivian (c. $135 \mathrm{Ma}$ ). This has important implications for geological interpretations offshore, where the identification of Early Cretaceous sills and lava flows in seismic records is directly relevant to current hydrocarbons exploration. 


\section{THE ONSHORE DYKE SWARMS}

Key features of Falkland Islands onshore geology are shown in Fig. 1b and are more fully described by Aldiss \& Edwards (1999) and Stone et al. (2005). At the southern extremity of West Falkland, a small outcrop of Proterozoic crystalline basement Cape Meredith Complex - has been dated at approximately 1100-1000 Ma (Jacobs et $a l ., 1999)$. The Proterozoic rocks are uncomformably overlain by a Siluro-Devonian to Carboniferous succession of clastic strata predominantly comprising quartzite, sandstone and mudstone. This succession is known as the West Falkland Group; it crops out over most of the western of the two main islands (ie, West Falkland) and is left unshaded in figure 1b. In the eastern of the two main islands - East Falkland - the West Falkland Group crops out in the north, whereas the south of East Falkland and its smaller peripheral islands are underlain by the tillite, mudstone and sandstone of the Carboniferous to Permian Lafonia Group, which is shaded grey in figure $1 \mathrm{~b}$. Jurassic and Cretaceous dolerite dykes are particularly numerous in West Falkland (Fig. 1b) where at least 300, possibly as many as 400, were identified in an aerial photo-interpretation by Greenway (1972). Distinct swarms are apparent and radiometric dates show an age range from Early Jurassic to Early Cretaceous.

The majority of the dykes are of Early Jurassic age. A swarm of broadly east-westtrending dykes (plagioclase-clinopyroxene-olivine dolerite) is concentrated in the southern part of West Falkland, with one component dyke providing an Ar-Ar date of $188 \pm 2 \mathrm{Ma}$ (Mussett \& Taylor 1994). A swarm of NE-SW-trending dykes (plagioclase-clinopyroxene-orthopyroxene dolerite) is mostly represented in West Falkland but a few of its component dykes occur in East Falkland: Ar-Ar dating has given a maximum age of 193 \pm 4 Ma from a dyke in West Falkland and 178.6 $\pm 4.9 \mathrm{Ma}$ from a dyke in East Falkland (Stone et al. 2008); two K-Ar dates of $176 \pm 7$ and $162 \pm 6$ Ma have been reported from the vicinity of Cape Meredith (Thistlewood et al. 1997). A K-Ar date of 192 $\pm 10 \mathrm{Ma}$, also from the vicinity of Cape Meredith (Cingolani \& Varela 1976), cannot be confidently assigned to any particular swarm. In the extreme southwest part of West Falkland a more variable pattern of dyke intrusion (noted by 
Greenway (1972) as an area of overlap) has been separated out as a distinct Cape

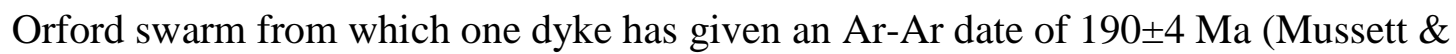
Taylor 1994). The dykes for which Ar-Ar dates are available are located in Fig. 1c.

The recent discovery of Early Cretaceous dykes in the Falkland Islands has been described by Stone et al. (2008 \& 2009) who noted that a commercial aeromagnetic survey, conducted in 2004 as part of an onshore mineral exploration programme, proved sharp, linear anomalies related to the presence of dolerite dykes. In addition to confirming and extending the Jurassic dyke swarms, the survey revealed a N-S swarm of about 40 previously undetected dykes distributed equally (though exposed only very rarely) across both East and West Falkland. One of these dykes in East Falkland was temporarily exposed in Pony's Pass Quarry, near Stanley (Figs. 1c and 3), and Ar-Ar dating of a sample from this locality, reported by Stone et al. (2008), gave an age of 121.3 $\pm 1.2 \mathrm{Ma}$ (Aptian). The magnetic anomaly coincident with the dyke has reversed polarity. We have subsequently obtained Ar-Ar dates (see below for details) within the range, approximately, 140-130 Ma (Valanginian-Hauterivian) from two other dykes from the N-S swarm, both in East Falkland (Fig. 1c): an exposed dyke 10$15 \mathrm{~m}$ wide discovered at Teal Creek, and a dyke approximately $12 \mathrm{~m}$ wide proved during mineral exploration drilling at Peat Banks, both localities in Lafonia. The Cretaceous dykes are all composed of plagioclase-clinopyroxene-orthopyroxene dolerite with a distinctive glassy groundmass. They are markedly Fe-rich compared to the Jurassic dykes (Mitchell et al. 1999: Stone et al. 2008, Supplementary Publication).

The Teal Creek dyke is coincident with a north-south, reversed magnetic anomaly and is exposed intermittently along a $5 \mathrm{~km}$, north-south linear zone. For at least part of this distance, one dolerite dyke about $15 \mathrm{~m}$ across is separated from a second, much thinner (>2 m across) dyke, by a narrow screen of country rock; two of the newly dated samples (PS711 and PS712) were collected at localities about $500 \mathrm{~m}$ apart on opposite sides of Teal Creek itself. The dyke proved in the Peat Banks borehole has provided the third of the dated samples reported in this paper (PS713); there is no surface exposure. From the nature of this dyke's aeromagnetic anomaly, which shows normal polarity, Stone et al. (2009) interpreted it as the local, shallow expression of a much deeper and larger, N-S intrusive body, the sampled section of the dyke having 
risen close to the present-day ground surface close to its intersection with a NE-SW fracture that had previously accommodated a dyke of Early Jurassic-age.

\section{MATERIALS AND METHODS}

Ar-Ar dating of dolerite samples from the dykes at Teal Creek and Peat Banks was carried out at the New Mexico Geochronological Research Laboratory. Spectra were obtained both from plagioclase separates and from groundmass (i.e. whole rock samples selected to avoid phenocrysts), but in all cases are somewhat disturbed (Fig. 4). The plagioclase separates give climbing spectra and have lower integrated ages than the groundmass; argon loss, reflecting a reheating or alteration event seems the most likely explanation. However, the plagioclase spectrum from one sample (PS 711: Fig. 4a) has a flat central portion that does meet plateau criteria and this gives a weighted mean age of $131 \pm 4 \mathrm{Ma}(\mathrm{MSWD}=1.70)$. The groundmass spectra are less discordant, but all three drop significantly in age over the course of the analysis. The most likely cause of this decline is ${ }^{39} \mathrm{Ar}$ recoil during irradiation from K-rich to Kpoor phases. In cases of recoil redistribution such as this, the best estimate of the intrusion age is the integrated age (also known as the total gas age) calculated by combining the data from all steps. With the exception of the example cited above, isochron ages generally have very high MSWD values (probably due to ${ }^{39} \mathrm{Ar}$ recoil redistribution) and so cannot be regarded as reliable.

\section{RESULTS}

Integrated whole-rock ages for the three analysed samples are as follows:

PS 711 (Teal Creek S: Fig. 4b)

PS 712 (Teal Creek N: Fig. 4c)

PS 713 (Peat Banks: Fig. 4d)
$133 \pm 4 \mathrm{Ma}$

(cf. plagioclase plateau age of $131 \pm 4 \mathrm{Ma}$ )

$$
138 \pm 4 \mathrm{Ma}
$$

Although if taken individually and in isolation these results lack reliability and precision, all four agree within analytical error, which provides some level of confidence. Taken together they suggest dyke intrusion at around $135 \mathrm{Ma}$, during the 
Valanginian or Hauterivian stages of the early Cretaceous. This is significantly earlier than the Aptian age of intrusion given by the Pony's Pass dyke. The Aptian age of 121.3 \pm 1.2 Ma (MSWD = 0.8) reported by Stone et al. (2008) is apparently of a reliable precision but does then question the homogeneity of the North-South oriented Cretaceous dyke swarm, an issue that is also raised by the variation in polarity of the aeromagnetic anomalies associated with the dykes (illustrated in Stone et al. 2008, figure 1).

Across the early Cretaceous swarm, the eastern dykes show reversed magnetic polarity but the majority of those occurring farther west have normal polarity. Of the c. 135 Ma dykes, the one at Teal Creek is reversed whilst the one at Peat Banks is normal. The overlapping ages of these dykes suggests that magmatism lasted long enough to span a magnetic reversal, of which there were several at around that time. The dated dyke at Pony's Pass Quarry has reversed polarity, though the $121 \mathrm{Ma}$ age places it within the early part of the normal polarity Cretaceous super-chron, the socalled Cretaceous quiet zone. The closest established interval of reversed polarity is M0r, which is dated at 124-125 Ma using the timescale of Gradstein et al. (2004).

\section{MAGMATISM IN THE OFFSHORE BASINS}

Evidence for magmatism in the offshore basins is so far limited to the Falkland Plateau Basin. Richards et al. (1996) described the geology of its then undrilled portions and identified a relatively thick (ca $2 \mathrm{~km}$ ) succession of Jurassic to earliest

Cretaceous rocks, which they dated by tying seismically back to DSDP boreholes on the Maurice Ewing Bank, some $600 \mathrm{~km}$ east of the archipelago, and to commercial boreholes in the Malvinas Basin, some $45 \mathrm{Km}$ or so to the west. Within this Jurassic to earliest Cretaceous section a series of high amplitude seismic reflectors were interpreted as sills and ascribed a probable early Cretaceous age. This age interpretation was made despite the evidence then available suggesting that only dykes of early Jurassic age were present onshore in the Falkland Islands. The interpretation was based on the offshore sills being intruded into Jurassic rocks and so of necessity being younger than their hosts. Richards et al. (1996) extended their argument to suggest that, conceivably, some of the onshore dykes may also prove to of early Cretaceous rather than early Jurassic age, and be genetically linked to the 
opening of the South Atlantic, an inference that appears to have been prescient, given the Aptian (ca $121 \mathrm{Ma}$ ) onshore dyke age reported by Stone et al. $(2008,2009)$ and the Valanginian-Hauterivian (ca $135 \mathrm{Ma}$ ) ages reported here.

Seismic basement in the Falkland Plateau Basin was considered by Richards et al. (1996) most likely to be Devono-Carboniferous sedimentary rocks possibly underlain by Precambrian igneous rocks. However, the only deep commercial borehole in the region at the time of writing (well 61/5-1 - see Figs. 2 and 4 for location - drilled by BHP Billiton in 2010) terminated at a depth of $2476 \mathrm{~m}$ below sea level, having encountered at least $60 \mathrm{~m}$ of aphyric, plagioclase-clinopyroxene-olivine dolerite at the base of the well. It is important to note here that the dolerites identified at the base of well 61/5-1 may not be truly representative of seismic basement in the basin, and indeed seismic character does change even just a short distance from the well. The dolerites may represent a sill intruded into or near basement at this locality, rather than widespread igneous basement. However, importantly, the petrography of the igneous rocks here is strikingly similar to that of the onshore, east-west Jurassic dyke swarm: plagioclase-clinopyroxene-olivine dolerite, variably porphyritic with phenocrysts of plagioclase and/or olivine. In contrast, both the onshore NE-SW Jurassic dykes and the north-south Cretaceous dykes are plagioclase-clinopyroxeneorthopyroxene dolerites (Brown, 1967; Mitchell et al., 1999; Stone et al. 2008). The offshore dolerites in well 61/5-1, like the onshore NE-SW Jurassic dykes, lack the distinctive glassy groundmass that comprises up to $25 \%$ of the Cretaceous dykes.

The succeeding Jurassic to Cretaceous and thin Cenozoic sedimentary fill of the basin above basement at the 61/5-1 location is interpreted as lying unconformably on the doleritic seismic basement penetrated at this locality. The only stratigraphic control on the age of the igneous basement is that it is overlain by an apparently Tithonian-aged section (based on the presence of Nannoconus globulus, N. globulus minor and Zeugrhabdotus embergeri). The Tithonian aged sedimentary rocks above the doleritic basement, coupled with the petrographic similarity to the onshore, Early Jurassic dykes, suggests that the basement rocks in this well may be of Early Jurassic age.

Stone et al. (2009) suggested that the identification of Aptian age dykes onshore may necessitate a reassessment of Richards et al.'s (1996) conclusions regarding the Early 
Cretaceous age of the sills in the Falkland Plateau Basin. However, the seismic amplitude anomalies reported as sills by Richards et al. (1996) can now be re-assessed utilizing a much more extensive network of commercial offshore seismic data than was available in 1996, coupled with the biostratigraphic dating of reflectors tied to well 61/5-1. These new data have enabled us to map out a much more widespread distribution of igneous rocks within the Jurassic to earliest Cretaceous section than was originally apparent. It is currently possible to demonstrate that the igneous rocks extend for almost $500 \mathrm{~km}$ in a NE-SW orientated zone, which is approximately $85 \mathrm{~km}$ wide and offset between 40 and $95 \mathrm{~km}$ to the east of the basin margin (Fig. 5a) and occur within or very near the top of the Valanginian section (Fig. 5b). Furthermore, the seismic character of the igneous rocks is now also recognized as quite complex. Richards et al. (1996) depicted the sills as potentially multi-layered and discrete bodies approximately 5 or $6 \mathrm{~km}$ long where identified in dip sections. From the more recent seismic data it is clear that, as well as forming typical sill-like patterns -i.e. saucer-shaped, with steep limbs and both concordant and discordant attitudes to bedding (Hansen \& Cartwright 2006) - the igneous rocks also exhibit seismic features more often associated with lava flows; most notable are a 'rubbly' seismic expression similar to that of lava flows described from, for example, the Faroe-Shetland Basin off the UK (Ritchie et al. 1999), and a much more continuous nature than is characteristic of sills (Fig. 5c and d). It is therefore possible that at least some of the seismic anomalies identified offshore represent lava flows rather than sills.

If the seismic anomalies do represent lava flows, these are likely to have been erupted during the probable early sag phase of evolution of the basin, following PermoTriassic or Jurassic rifting (Richards et al. 1996). Their stratigraphic position makes it more likely that they are Valanginian to possibly Hauteriavian aged features, similar in age to the new dyke dates we report from onshore, rather than to the Aptian dyke(s) reported by Stone et al. (2008). The suspected lavas occupy a stratigraphical position immediately interfingering with the lowest occurrence of the black, source-rockquality shales, identified by seismic reflection ties back to the DSDP boreholes on the Maurice Ewing Bank (Richards et al., 1996). In DSDP boreholes 330 and 511 the black shales range in age from Oxfordian to Aptian, but the Berriasian-Hauterivian interval is revealed as one of uplift and erosion (Lorenzo \& Mutter, 1988). It is represented by an unconformity which may reflect an uplift event in the Falkland 
Plateau area driven by the Valanginian-Hauterivian magmatism. Contemporaneous uplift has also been recognized in two offshore wells (14/9-1 and 14/13-1) drilled in the North Falkland Basin (Richards \& Hillier 2000a), possibly lending credence to a hypothesis of regional uplift across the entire Falklands Plateau during the late Valanginian. Furthermore, uplift of the Falklands Platform to the west of the Falkland Plateau Basin during the Valanginian-Hauerivian may well have led to the development of the eastwards prograding deltas that infilled the basin in the Early Cretaceous (Fig. 5b). These deltas were described by Richards et al. (2006) who ascribed them an Albian to Cenomania age, which has been borne out by biostratigrahic analyses of the 61/5-1 well, although an Aptian age has been ascribed to the oldest of the deltaic sequences in the well.

\section{THE REGIONAL CONTEXT OF FALKLANDS MESOZOIC MAGMATISM}

The fundamental cause of the magmatism in the Falkland Plateau Basin, and the uplift there and elsewhere, is not definitively understood, but one possibility was thought to be underplating of the Falkland Plateau Basin as a result of its development within the influence of the Karoo-Ferrar plume, as described by Kimbell \& Richards (2008). However, as noted below, the 180 Ma peak of Karoo-Ferrar magmatism in South Africa and Antarctica is significantly older than the $135 \mathrm{Ma}$ ages reported here for the $\mathrm{N}-\mathrm{S}$ onshore dykes and extrapolated from the lavas in the Falkland Plateau Basin. Whilst the early Jurassic, Karoo-Ferrar hotspot may have been responsible for underplating of the Falkland Plateau Basin during its initial extension, it is unlikely that heating continued long enough to influence early Cretaceous dyke injection onshore in the Falklands and coeval sill/lava development offshore. This would be particularly the case if the basin's seismic basement, as penetrated locally in the vicinity of the 61/5-1 well and unconformably overlain by sedimentary fill, can indeed be correlated with the $\mathrm{ca} 188 \mathrm{Ma}$, Early Jurassic, east-west dyke swarm of onshore West Falklands.

It is more likely that the Cretaceous dykes are related to regional stresses associated with South Atlantic opening and Gondwana fragmentation, and it seems logical that lava extrusion and/or sill intrusion offshore in the Valanginian-Hauterivian would be related to the same regional stress field. This regional stress system led to oceanic 
development to the north of the Falkland Plateau, and to east-west directed extension in the North Falkland Basin (Richards \& Hillier 2000a; Stone et al. 2009). It would also inevitably have led to both local footwall uplift and regional upwarping as the new South Atlantic Ocean formed, thereby providing a mechanism for the generation of the Valanginian unconformities observed in the basins surrounding the Falklands. Furthermore, uplift of footwall and platform areas would have led to the creation of sand source areas available for erosion, with associated transport of sand into the surrounding sedimentary basins at various times (Fig. 6) providing potential reservoir targets in the offshore basins.

The Early Jurassic, c. 178 Ma Ar-Ar date from the NE-SW dyke at Port Sussex, East Falkland (Stone et al. 2008), and the slightly older ages reported from West Falkland (Mussett \& Taylor 1994), are closely aligned with the c. 180-183 Ma peak of KarooFerrar magmatism in South Africa and Antarctica (e.g. Duncan et al. 1997; Jourdan et al. 2005). There is general agreement that this regional phase of early Jurassic magmatism, spanning the South African and Antarctic segments of Gondwana, marked the beginning of the break-up of that supercontinent. More specifically, Mitchell at al. (1999) considered that the Falklands Jurassic dykes marked an overlap between the Karoo and Ferrar provinces, with the east-west swarm of Karoo-type dolerite and the NE-SW swarm showing more affinity to Ferrar-type dolerite.

The Early Cretaceous dykes from the Falkland Islands, with ages between about 135 and $121 \mathrm{Ma}$, must be related more to the early stages of Atlantic opening than to the initial break-up of Gondwana. The Falklands ages span the range obtained farther north from the Paraná-Etendeka flood basalts and associated dykes, which are now preserved on opposite sides of the South Atlantic (Fig. 7a). Those rocks have generally been thought to have arisen between about 134 and $129 \mathrm{Ma}$ and were emplaced as the fragmenting Gondwana drifted across the Tristan da Cunha hot spot (Turner et al. 1994; Renne et al. 1996; Peate 1997; Deckart et al. 1998). More recent work (Thiede and Vasconcelos 2010) has confirmed the rapid eruption of the Paraná basalts at $134.7 \pm 1 \mathrm{Ma}$. The association of the Paraná-Etendeka magmatism with the Tristan plume precludes any direct link with intrusion of the Early Cretaceous dykes in the Falklands, but both phenomena can be related to the clockwise rotation of South America away from Africa during initiation of Atlantic spreading. An 
assumption of rigid continental plates during this process may not allow for continental reconstruction without significant misfits, a problem addressed by, for example, Nürnberg and Müller (1991), who noted the need for a complex combination of rift and strike-slip adjustments. In many pre-Atlantic reconstructions, the Falkland Islands and Falkland Plateau are regarded as a rigid extension of the South American plate (Fig. 7b) despite proposals (derived largely from onshore geology) that the region is an amalgamation of several rotated microplates (e.g. Marshall 1994; Storey et al. 1999; cf Adie 1952). Alternative proposals (derived largely from offshore geology) account for the break-up of Gondwana without recourse to the mantle-plume-driven generation of rotated microplates (e.g. Eagles \& Vaughan 2009). This apparent conflict between regional interpretations derived, respectively, from onshore and offshore data remains an obstacle to a full understanding of the tectonic history of the South Atlantic, though some recent reconstructions do attempt a reconciliation (eg. Torsvik et al. (2009, figure 12).

The Early Cretaecous development of the South Atlantic was accompanied by extensive magmatism that has been detected as seaward-dipping reflectors (and the associated ' $G$ ' magnetic anomaly) along the conjugate margins, and also by highvelocity zones at the base of the crust indicative of magmatic underplating (Gladczenko et al. 1997; Franke et al. 2007; Blaich et al. 2009). The geophysical evidence indicates along-margin variation in magmatic activity, with a distinct southward decrease in magmatism across both the Colorado transfer system on the Argentinian margin and the conjugate Hope transfer system on the South African margin (Franke et al. 2007; Blaich et al. 2009). In the latter area an early Cretaceous dyke swarm has been identified on the SW African margin in the Cape Peninsula False Bay area (Day 1987; Reid 1990; Reid et al. 1991; Trumbull et al. 2007). The False Bay dykes (Fig. 7b) have yielded a K-Ar age of 132 \pm 6 Ma (Reid et al., 1991), and a Ar-Ar plagioclase age of 131.3 $\pm 1.3 \mathrm{Ma}$ (Stewart et al. 1996). Farther south, between the Colorado-Hope $(\mathrm{CH})$ and Falkland-Agulhas(FA) fracture systems (Fig. 7b), evidence for limited volcanic activity comes from offset continuations of the Ganomaly in this segment on both margins (Rabinowitz \& LaBreque 1979; Max et al. 1999). The presence of these coeval, Early Cretaceous volcanic margins to the South Atlantic Ocean to the north of the Falkland Islands fits well with the evidence for a contemporary tectonic regime in the Falklands area that was conducive to dyke 
intrusion. Further, the palaeogeographical reconstruction of Torsvik et al. (2009) suggests the initiation of sea-floor spreading within the $\mathrm{CH}$ to FA Atlantic segment during the Hauterivian at about 130Ma (op. cit. figure 12c), at about the same time as, to the south, dyke intrusion in the Falklands Islands and sill/lava emplacement in the Falkland Plateau Basin (Fig. 7b).

\section{CONCLUSIONS}

Recently acquired aeromagnetic data for the Falkland Island, coupled with Ar-Ar dating, show that previous interpretations of the onshore Falkland Islands dyke swarms are inadequate. In particular, a swarm of north-south-trending Cretaceous dykes with ages in the c.135-121 Ma range (though in a regional sense the $121 \mathrm{Ma}$ date looks suspiciously isolated) has now been recognized, cutting across the previously identified east-west and NE-SW Jurassic swarms which have ages in the 188-178 Ma range. The Cretaceous, N-S dykes are reversely magnetised in the east of the Falklands archipelago, but show both normal and reversed polarities in the west, suggesting that intrusion spanned a magnetic reversal

The Jurassic dykes are generally considered a part of the regional Karoo-Ferrar magmatism linked to the initial break-up of Gondwana. Rock chippings recovered from seismic basement beneath Late Palaeozoic strata of the Falkland Plateau Basin are petrographically similar to dolerite characteristic of the c. $188 \mathrm{Ma}$, east-west dyke swarm seen onshore in West Falkand, implying a similar Early Jurassic age for the basement and an origin for it within the Karoo-Ferrar magmatic province. We consider the Early Cretaceous magmatism, both onshore and offshore to be associated with the later extension phases of the Falklands Plateau and rifting of the North Falklands Basin as the South Atlantic Ocean initially opened. The ca $135 \mathrm{Ma}$ ages obtained for the onshore dykes add credence to the Valangian-Hauterivian age deduced for likely lava flows detected on seismic lines from the Falkland Plateau Basin, and to the Berriasian-Hauterivian uplift phase determined from seismic data and DSDP boreholes. The extent of the offshore Early Cretaceous magmatism, defined by the distribution of both sills and lavas, is much greater than previously supposed. 


\section{ACKNOWLEDGEMENTS}

We thank Falkland Gold and Minerals Ltd for making available data from the 2004 aeromagnetic survey and samples from the Peat Banks borehole; in particular we gratefully acknowledge the assistance of Derek Reeves, the project manager. We also grateful to Falkland Oil and Gas Ltd for kindly allowing release of data from the exploration well 61/5-1, and thank FOGL's exploration director Colin More for his helpful comments on the manuscript. Our thanks go to Derek Ritchie, Graeme Eagles, Graeme Taylor and Roger Swart for helpful comments on earlier versions of this paper, and to Sandy Henderson for assistance in the preparation of figures. This paper is published by permission of the Falkland Islands Government and the Executive Director, British Geological Survey (NERC).

\section{REFERENCES}

ADIE, R. J. 1952. The position of the Falkland Islands in a reconstruction of Gondwanaland. Geological Magazine, 89, 401-410.

ALDISS, D. T. \& EDWARDS, E. J. 1999. The Geology of the Falkland Islands. British Geological Survey Technical Report, WC/99/10.

ANDERSSON, J. G. 1907. Contributions to the geology of the Falkland Islands. Wissenschaftliche Ergebnisse der Schwedischen Sudpolar-expedition 1901-1903, 3 (Lief. 2), 38 pp.

BAKER, H. A. 1924. Final Report on Geological Investigations in the Falkland Islands, 1920-1922. Government Printer, Stanley. 38 pp, 18 figs.

BARKER P. F \& DALZIEL, I W. D. (eds). 1976. Initial Reports of the Deep Sea Drilling Project, Leg 36. US Government Printing Office, Washington. 
BARKER, P. F. 1999. Evidence for a volcanic rifted margin and oceanic crustal structure for the Falkland Plateau Basin. Journal of the Geological Society, London, 156, 889-900.

BLAICH, O. A., FALEIDE, J. I., TSIKALAS, F., FRANKE, D. \& LEÓN, E. 2009. Crustal-scale architecture and segmentation of the Argentine margin and its conjugate off South Africa. Geophysical Journal International, 178, 85-105.

BROWN, J. W. 1967. Jurassic dolerites from the Falkland Islands and Dronning Maud Land. British Antarctic Survey Bulletin, 13, 89-92.

CINGOLANI, C. A. \& VARELA, R. 1976. Investigaciones geologicas y geochronologicas en el extremo sur de la isla Gran Malvina, sector do Cabo Belgrano (Cabo Meredith), Islas Malvinas. In: Actas del sexto congreso Geologico Argentino, Buenos Aires, 457-473.

DAY, R. W. 1987. False Bay dolerites. Annals of the Geological Survey of South Africa, 21, 1-7.

DECKART, K., FERAUD, G., MARQUES, L. SS \& BERTRAND, H. 1998. New time constraints on dyke swarms related to the Parana-Etendeka magmatic province, and subsequent South Atlantic opening, southeastern Brazil. Journal of Volcanology and Geothermal Research, 80, 67-83.

DUNCAN, R. A., HOOPER, P. R., REHACEK, J., MARSH, J. S. \& DUNCAN, A. R. 1997. The timing and duration of the Karoo igneous event, southern Gondwana. Journal of Geophysical Research, 102, 18.127-18.138.

DU TOIT, A. L. 1927. A geological comparison of South America with South Africa. Carnegie Institution, Washington. 158 pp.

DU TOIT, A. L. 1937. Our Wandering Continents. Oliver \& Boyd, Edinburgh \& London, 366 pp. 
EAGLES, G. \& VAUGHAN, P.M. 2009. Gondwana breakup and plate kinematics: business as usual. Geophysical Research Letters, 36, in press.

FRANKE, D., NEBEN, S., LADAGE, S., SCHREKENBERGER, B \& HINZ, K. 2007. Margin segmentation and volcano-tectonic architecture along the margin off Argentina/Uruguay, South Atlantic. Marine Geology, 244, 46-67.

GLADCZENKO, T.P., HINZ, K., ELDHOLM, O., MEYER, H., NEBEN, S. \& SKOGSEID, J., 1997. South Atlantic volcanic margins. Journal of Geophysical Research, 154, 465-470.

GRADSTEIN, J.G., OGG, A.G. \& SMITH, A.G. 2004. A Geologic Time Scale 2004. Cambridge University Press, Cambridge.

GREENWAY, M. E. 1972. The geology of the Falkland Islands. British Antarctic Survey Scientific Reports, 76, 42 pp.

HALLE, T. G. 1911. On the geological structure and history of the Falkland Islands. Bulletin of the Geological Institution of the University of Uppsala, 11, 115-229.

HANSEN, D.M. \& CARTWRIGHT, J. 2006. Saucer-shaped sill with lobate morphology revealed by 3D seismic data: implications for resolving a shallow-level sill emplacement mechanism. Journal of the Geological Society, London, 163, 509 523.

JACOBS, J., THOMAS, R. J., ARMSTRONG, R. A. \& HENJES-KUNST, F. 1999. Age and thermal evolution of the Mesoproterozoic Cape Meredith Complex, West Falkland. Journal of the Geological Society, London, 156, 917-928.

JOURDAN, F., FÉRAUD, G., BERTRAND, H., KAMPUNZU, A. B., TSHOSO, G., WATKEYS, M. K. \& LE GALL, B. 2005. Karoo large igneous province: Brevity, origin and relation to mass extinction questioned by new ${ }^{40} \mathrm{Ar} /{ }^{39} \mathrm{Ar}$ age data. Geology, 33, 745-748. 
KIMBELL, G. S. \& RICHARDS, P.C. 2008. The three-dimensional lithospheric structure of the Falkland Plateau region based on gravity modeling. Journal of the Geological Society, London, 165, 795-806.

LORENZO, J.M. \& MUTTER, J.C. 1988. Seismic stratigraphy and tectonic evolution of the Falklands/Malvinas Plateau. Revista Brasileira de Geociencias, 18, 191-200.

MARSHALL, J. E. A. 1994. The Falkland Islands: a key element in Gondwana palaeogeography. Tectonics, 13, 499-514.

MAX, M.D., GHIDELLA, M., KOVACS, L., PATERLINI, J.A. \& VALLADARES, J.A. 1999. Geology of the Argentine continental shelf and margin from aeromagnetic survey. Marine and Petroleum Geology, 16, 41-64.

MITCHELL, C., TAYLOR, G. K., COX, K. G. \& SHAW, J. 1986. Are the Falkland Islands a rotated microplate? Nature, 319, 131-134.

MITCHELL, C., ELLAM, R. M. \& COX, K. G. 1999. Mesozoic dolerite dykes of the Falkland Islands: petrology, petrogenesis and implications for geochemical provinciality in Gondwanaland low-Ti basaltic rocks. Journal of the Geological Society, London, 156, 901-916.

MUSSETT, A. E. \& TAYLOR, G. K. $1994 .{ }^{40} \mathrm{Ar}-{ }^{39} \mathrm{Ar}$ ages for dykes from the Falkland Islands with implications for the break up of southern Gondwanaland. Journal of the Geological Society, London, 151, 79-81.

NÜRNBERG, D. \& MÜLLER, R. D. 1991. The tectonic evolution of the South Atlantic from Late Jurassic to present. Tectonophysics, 191, 27-53.

PEATE, D. W. 1997. The Paraná-Etendeka Province. In: Mahoney, J. J. \& Coffin, F. (eds) Large Igneous Provinces: Continental, Oceanic and Planetary Flood Volcanism. American Geophysical Union, Geophysical Monograph 100, 217-245. 
RABINOWITZ, P.D. \& LABRECQUE, J. 1979. The Mesozoic South Atlantic Ocean and evolution of its continental margins. Journal of Geophysical Research, 84, 59736002.

REID, D. L. 1990. The Cape Peninsula dolerite dike swarm, South Africa. In:

PARKER, A. J., RICKWOOD, P. C. \& TURNER, D. H. (eds), Mafic Dikes and Emplacement Mechanisms. A. A. Balkema, Rotterdam, The Netherlands. 325-334.

REID, D. L., ERLANK, A. J. \& REX, D. C. 1991. Age and correlation of the False Bay dolerite dike swarm, south-western Cape, Cape Province. South African Journal Geology, 94, 155-158.

RENNE, P. R., GLEN, J. M., MILNER, S. C. \& DUNCAN, A. R. 1996. Age of Etendeka flood volcanism and associated intrusions in southwestern Africa. Geology, 24, 659-662.

RICHARDS, P.C. \& HILLIER, B.V. 2000a. Post-drilling analysis of the North Falkland Basin - Part 1: tectono-stratigraphic framework. Journal of Petroleum Geology, 23, 253-272.

RICHARDS, P.C. \& HILLIER, B.V. 2000b. Post-drilling analysis of the North Falkland Basin - Part 2: petroleum systems and future prospects. Journal of Petroleum Geology, 23, 273-292.

RICHARDS, P.C., DUNCAN, I., PHIPPS, C., PICKERING, G., GRZYWACZ, J., HOULT, R. AND MERRITT, J. 2006. Exploring for fan and delta sandstones in the offshore Falklands basins. Journal of Petroleum Geology, 29, 199-214.

RICHARDS, P. C., GATLIFF, R. W., QUINN, M. F., WILLIAMSON, J. P. \& FANNIN, N. G. T. 1996. The geological evolution of the Falkland Islands continental shelf. In: STOREY, B. C., KING, E. C. \& LIVERMORE, R. A. (eds) Weddell Sea Tectonics and Gondwana Break-up, Geological Society, London, Special Publications, 108, 105-128. 
RITCHIE, J.D, GATLIFF, R.W. \& RICHARDS, P.C. 1999. Early Tertiary magmatism in the offshore NW UK margin and surrounds. In: FLEET, A.J. AND BOLDY, S.A.R. (eds) Petroleum Geology of Northwest Europe: Proceedings of the $5^{\text {th }}$ Conference, 573-584.

THIEDE, D. S. \& VASCONCELOS, P. M. 2010. Paraná flood basalts: Rapid extrusion hypothesis confirmed by new ${ }^{40} \mathrm{Ar} /{ }^{39} \mathrm{Ar}$ results. Geology, 38, 747-750.

STEWART, K., TURNER, S., KELLEY, S., HAWKESWORTH, C., KIRSTEIN, L. \& MANTOVANI, M. 1996. 3-D ${ }^{40} \mathrm{Ar}-{ }^{39} \mathrm{Ar}$ geochronology in the Paraná continental flood basalt province. Earth and Planetary Science Letters, 143, 95-109.

STONE, P., ALDISS, D. A. \& EDWARDS, E. J. 2005. Rocks and Fossils of the Falkland Islands. British Geological Survey for Department of Mineral Resources, Falkland Islands Government. Keyworth, Nottingham. 60 pp.

STONE, P., RICHARDS, P. C., KIMBELL, G. S., ESSER, R. P. \& REEVES, D. 2008. Cretaceous dykes discovered in the Falkland Islands: implications for regional tectonics. Journal of the Geological Society, London, 165, 1-4.

STONE, P., KIMBELL, G. S. \& RICHARDS, P. 2009. Rotation of the Falklands microplate reassessed after recognition of discrete Jurassic and Cretaceous dyke swarms. Petroleum Geoscience, 15, 279-287.

STOREY, B. C., CURTIS, M. L., FERRIS, J. K., HUNTER, M .A. \& LIVERMORE, R. A. 1999. Reconstruction and break-out model for the Falkland Islands within Gondwana. Journal of African Earth Sciences, 29, 153-163.

STOREY, B. C., VAUGHAN, A. P. M. \& MILLAR, I. L. 1996. Geodynamic evolution of the Antarctic Peninsula during Mesozoic times and its bearing on Weddell Sea history. . In: STOREY, B. C., KING, E. C. \& LIVERMORE, R. A. (eds) Weddell Sea Tectonics and Gondwana Break-up, Geological Society, London, Special Publications, 108, 87-103. 
TAYLOR, G. K. \& SHAW, J. 1989. The Falkland Islands: New palaeomagnetic data and their origin as a displaced terrane from southern Africa. In: HILLHOUSE, J. W. (ed.) Deep structure and past kinematics of accreted terranes. Geophysical Monographs, 50, 59-72.

THISTLEWOOD, L., LEAT, P. T., MILLAR, I. L., STOREY, B. C. \& VAUGHAN, A. P. M. 1997. Basement geology and Palaeozoic-Mesozoic mafic dykes from the Cape Meredith Complex, Falkland Islands: a record of repeated intracontinental extension. Geological Magazine, 134, 355-367.

TORSVIK, T. H., ROUSSE, S., LABAILS, C. \& SMETHURST, M. A. 2009. A new scheme for the opening of the South Atlantic Ocean and the dissection of an Aptian salt basin. Geophysical Journal International, 177, 1315-1333.

TRUMBULL, R. B., REID, D. L., DE BEER, C., VAN ACKEN, D. \& ROMER, R. L. 2007. Magmatism and continental breakup at the west margin of southern Africa: A geochemical comparison of dolerite dikes from northwestern Namibia and the Western Cape. South African Journal of Geology, 110, 477-502.

TURNER, S., REGELOUS, M., KELLEY, S., HAWKESWORTH, C. \& MANTOVANI, M. 1994. Magmatism and continental break-up in the South Atlantic: high precision ${ }^{40} \mathrm{Ar}-{ }^{39} \mathrm{Ar}$ geochronology. Earth and Planetary Science Letters, 121, 333-348.

WHITE, R. \& McKENZIE, D. 1989. Magmatism at rift zones: The generation of volcanic continental margins and flood basalts. Journal of Geophysical Research, 94, 7685-7729. 


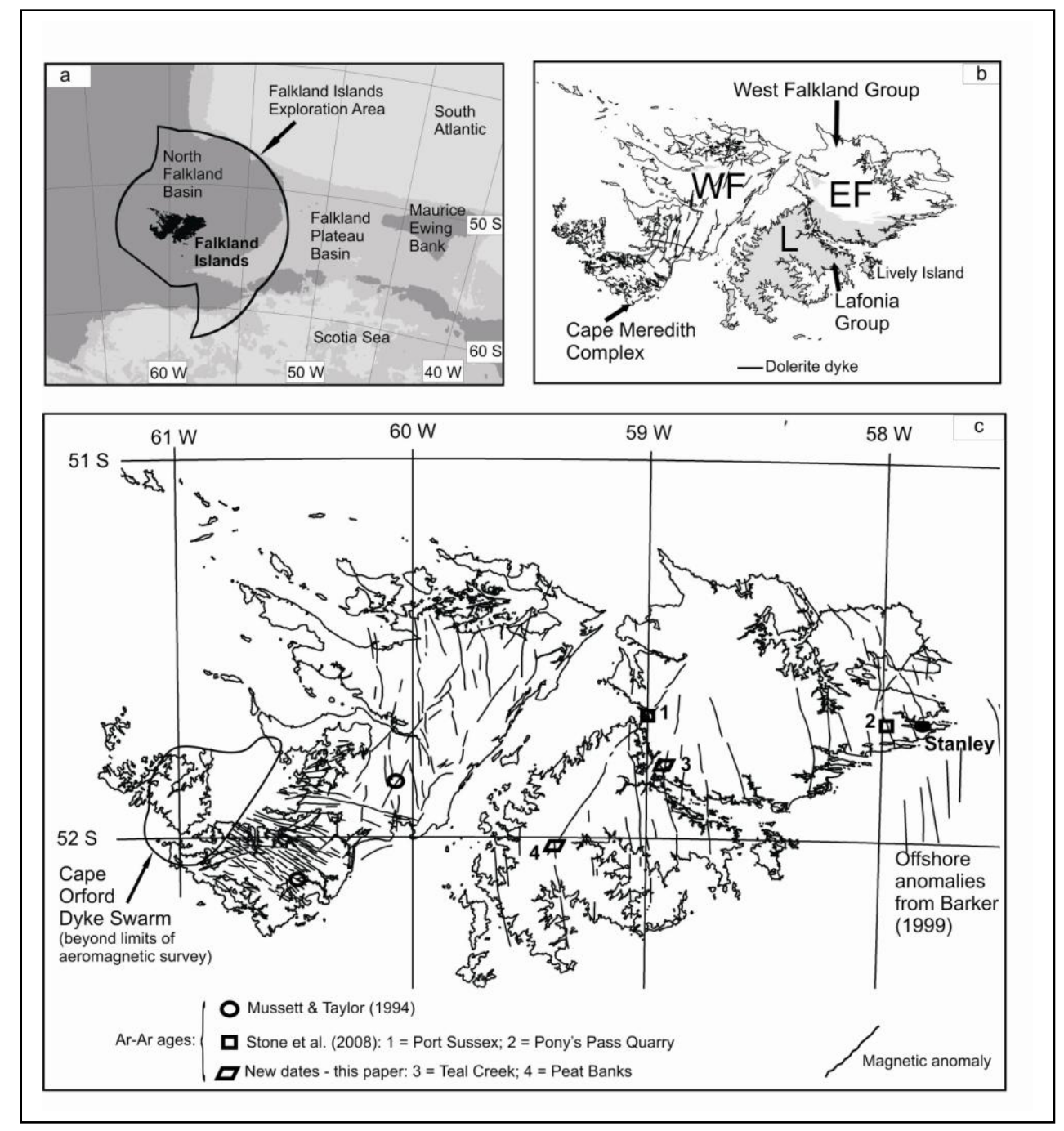

Figure 1. Location map and outline geology for the Falkland Islands: a) the regional setting at the western end of the Falkland Plateau, South Atlantic Ocean, with bathymetry represented by the grey scale from darkest $=$ shallowest water $(<1500 \mathrm{~m}$ approximately) to palest $=$ deepest water $(>2500 \mathrm{~m}$ approximately); b) outline onshore geology for the Falkland Islands (WF = West Falkland, EF = East Falkland, L = Lafonia); c) Linear aeromagnetic anomalies interpreted as dolerite dykes, showing the locations of the analysed and dated samples - note that the aeromagnetic survey covered only the two main islands and extended neither to the western promontories of West Falkland nor to the smaller offshore islands (for precise survey boundaries and identification of normal or reversed anomaly characters see Stone et al. 2008, figure 1 or Stone et al. 2009, figure 3). 


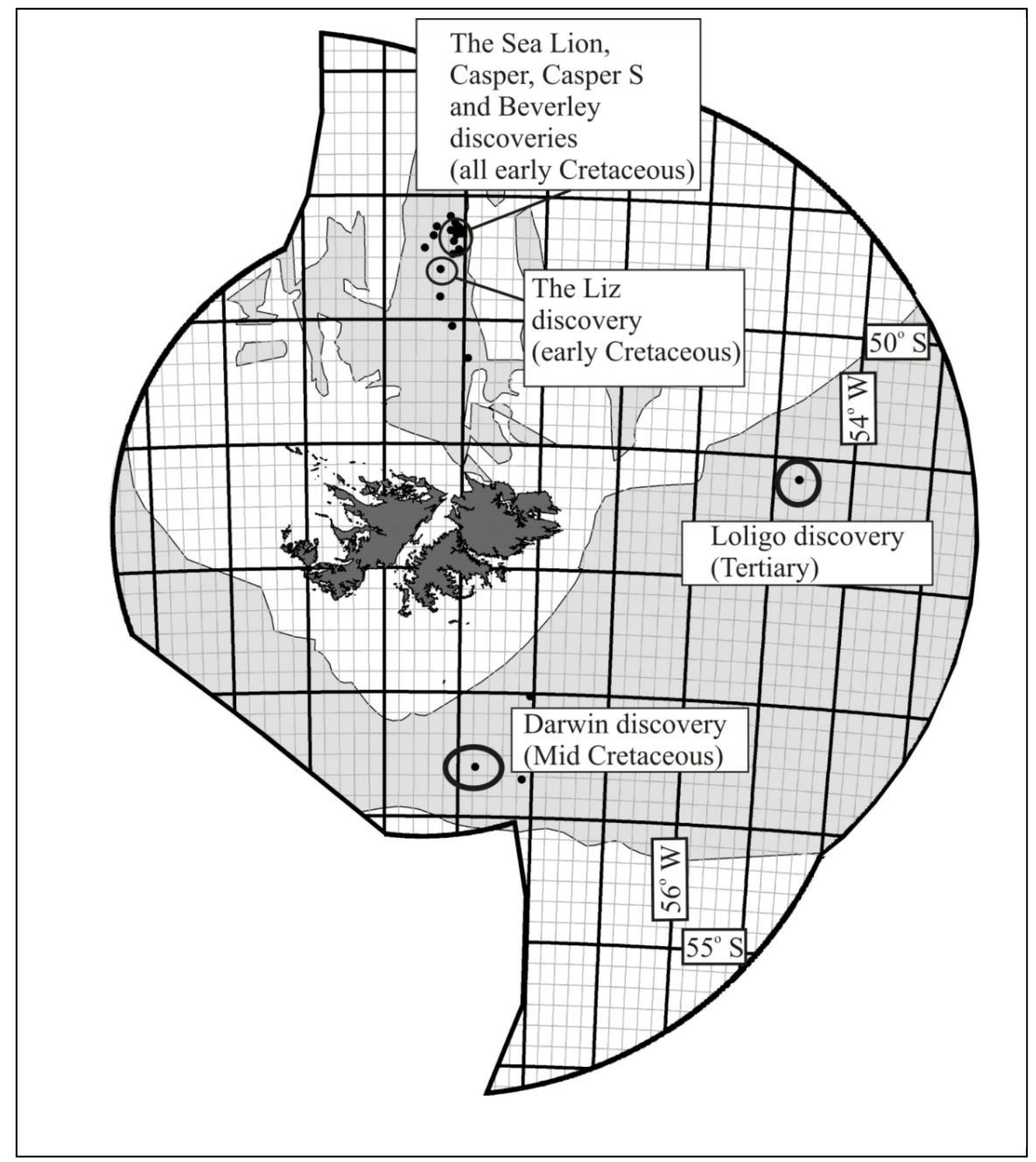

Figure 2. Location of wells and discoveries in the Falklands offshore area. Grey shaded areas offshore represent the distribution of the Mesozoic-Cenozoic basins. Well positions shown as black dots. 


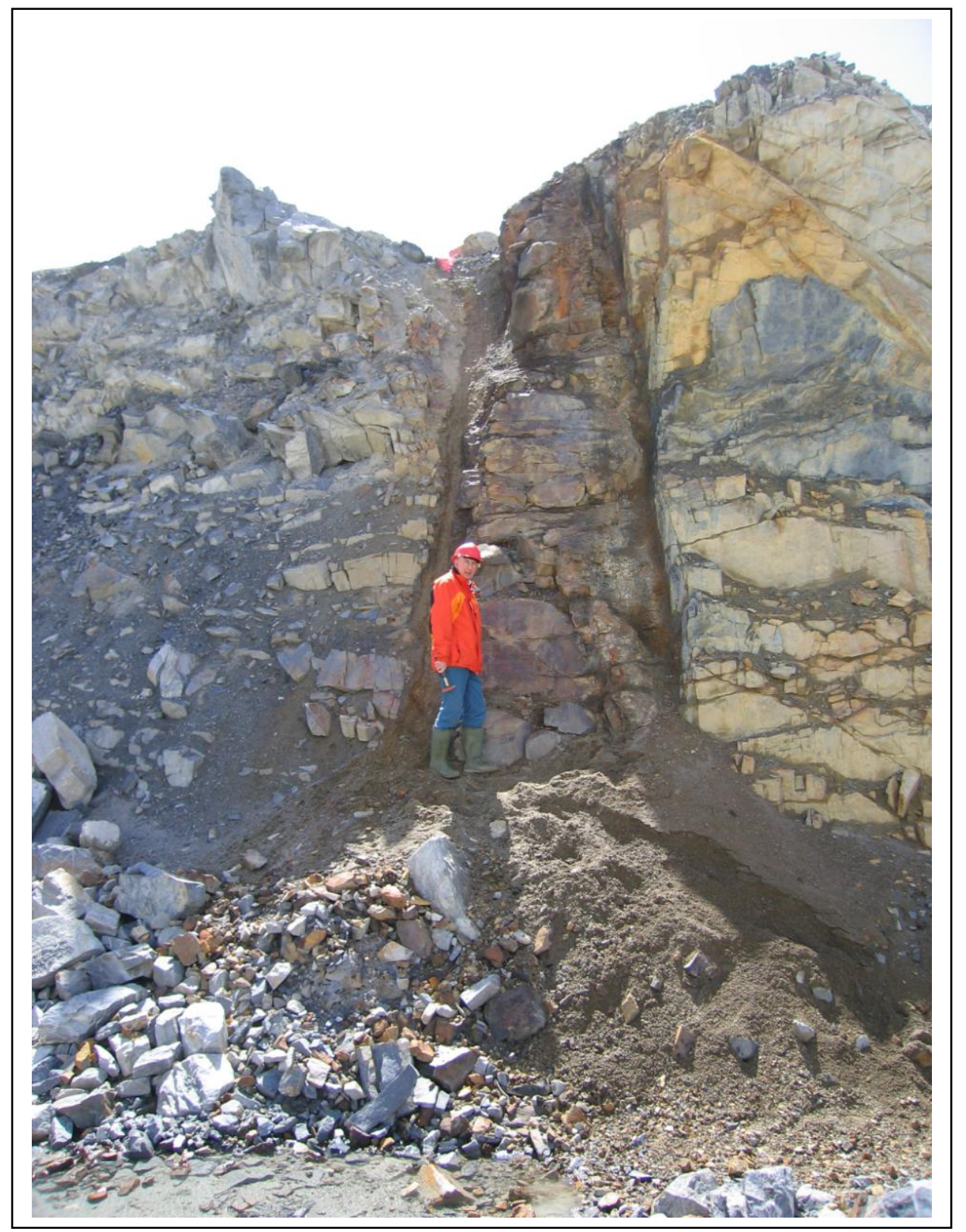

Figure 3. The Early Cretaceous dolerite dyke exposed in Pony's Pass Quarry near Stanley during 2009. NGS Image P696274. Copyright BGS (NERC). 


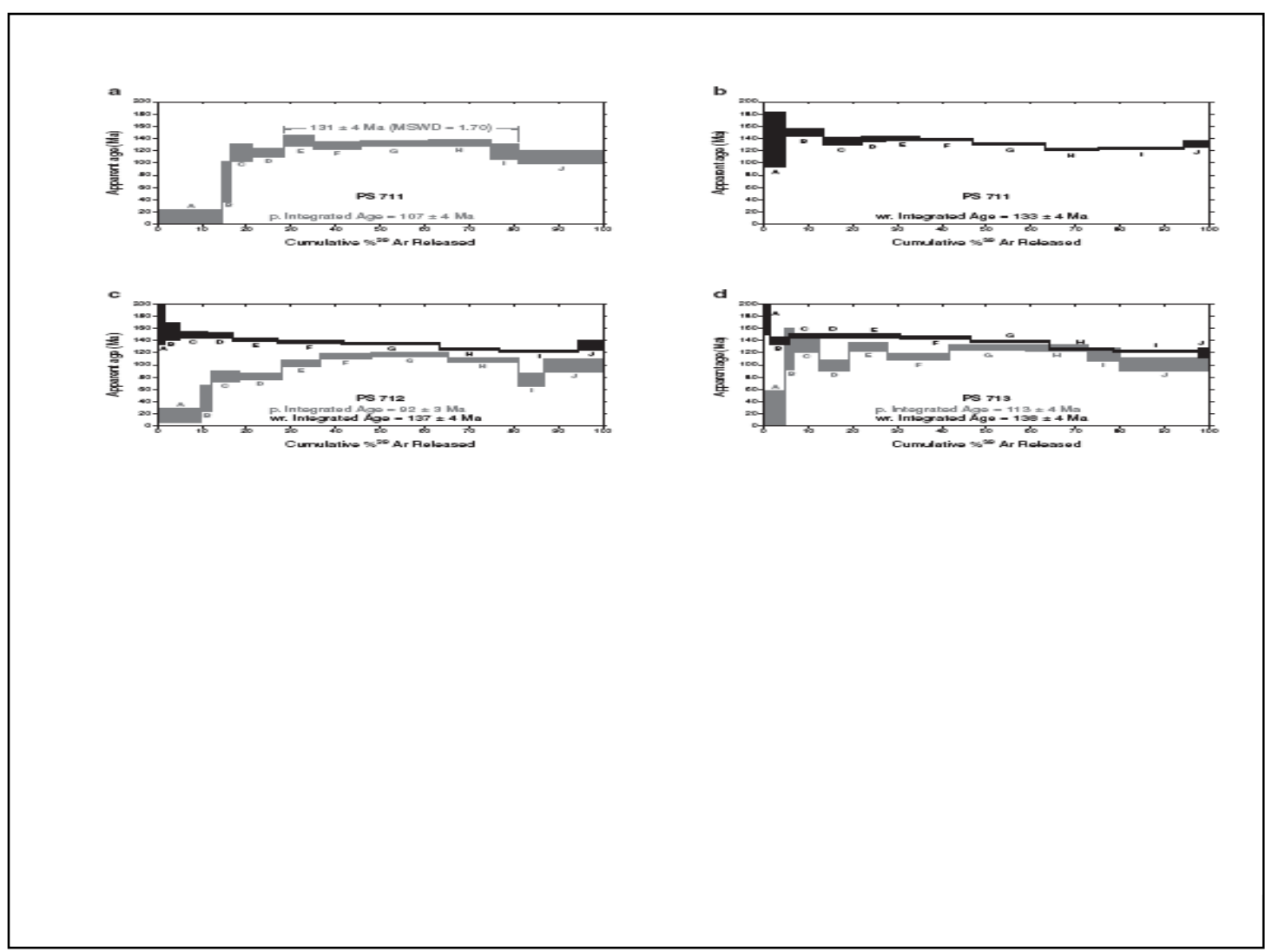

Figure 4. Ar-Ar spectra for dolerite samples from the onshore, N-S dyke swarm in East Falkland: a) results from plagioclase (p) separate, Teal Creek South (PS 711); b) whole rock (wr) results from Teal Creek South (PS 711); c) plagioclase (p) and whole rock (wr) results from Teal Creek North (PS 712); d) plagioclase (p) and whole rock (wr) results from Peat Banks (PS 713). 


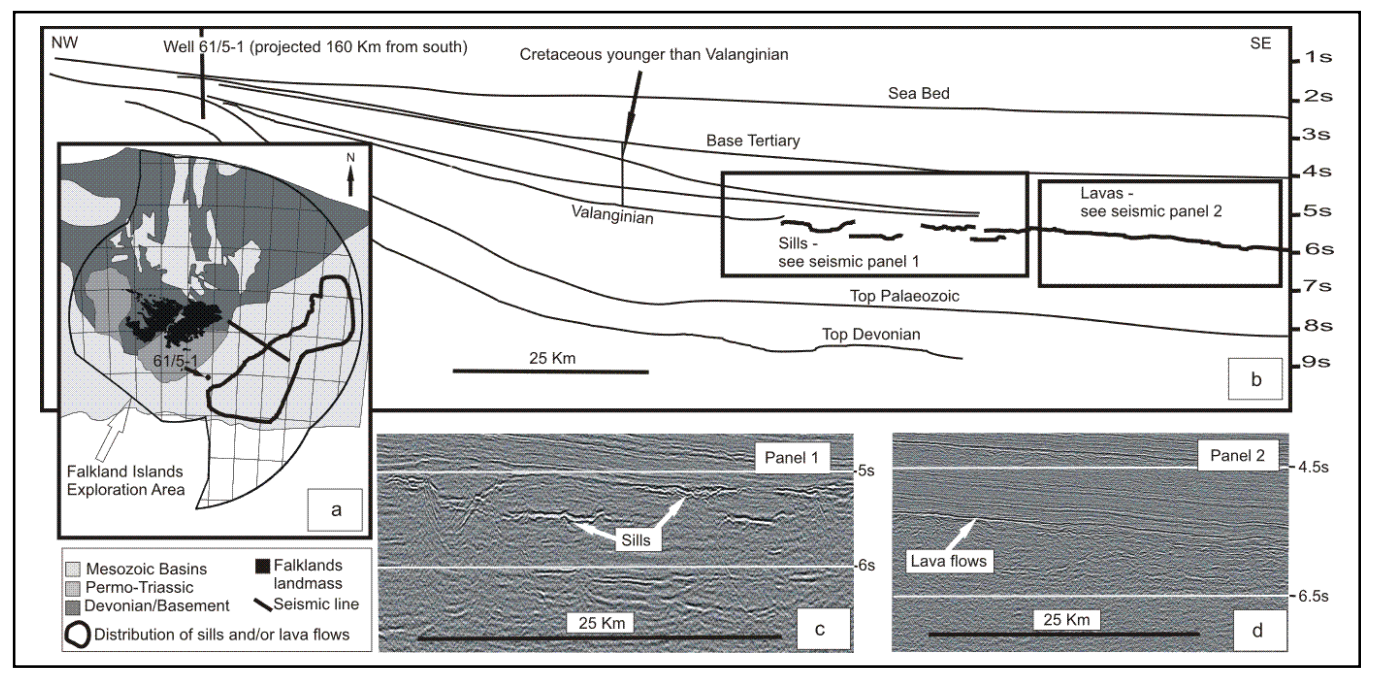

Figure 5. a) Distribution of sills and lava flows in the Falkland Plateau Basin; b) line drawing derived from seismic line acquired by Western-Geco in the Falkland Plateau Basin in 1993, with stratigraphic interpretation provided by regional mapping; c) seismic panel illustrating sills in the offshore; d) seismic panel illustrating potential lava flows. Depth indicators on seismic line drawing and panels is in Two-WayTravel Time (TWT). Note the different vertical and horizontal scales for seismic panels 1 and 2 (figures $5 \mathrm{c}$ and $5 \mathrm{~d}$ ). 


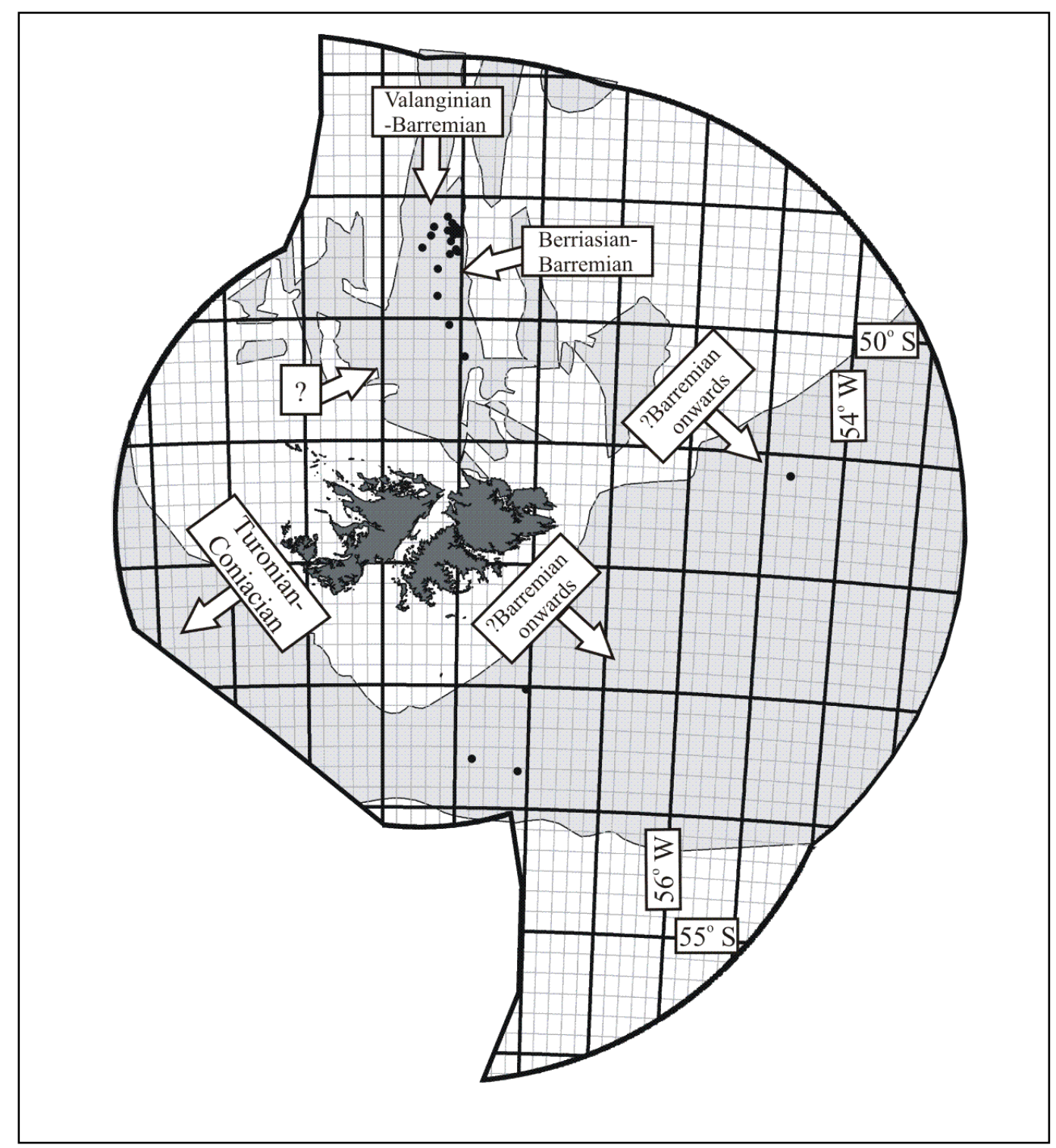

Figure 6. The relative timings and directions of sand supply to the offshore basins as a result of platform uplift in the region. 


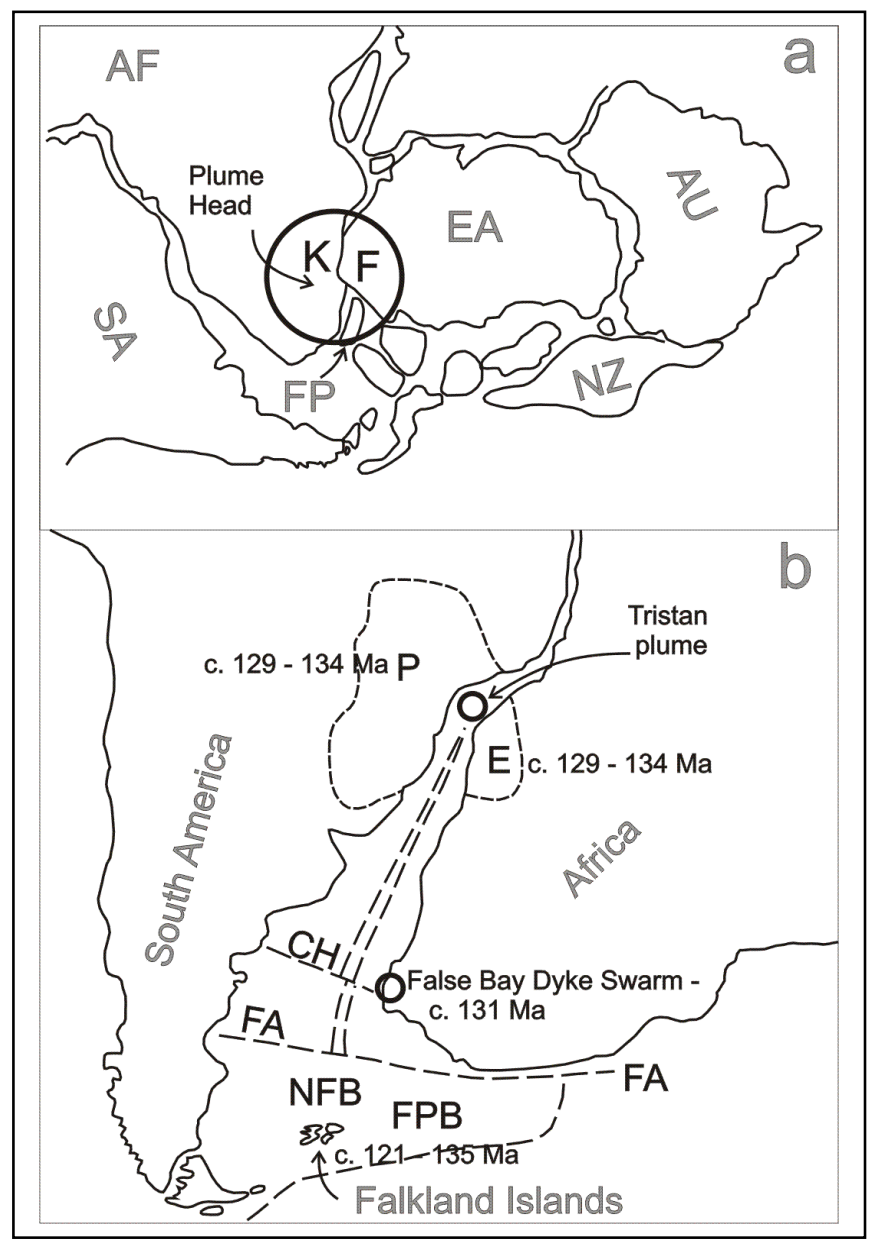

Figure 7. Pre- and post-Jurassic palaeogeographical reconstructions for the 'South Atlantic' sector of Gondwana: a) In pre-Jurassic reconstructions the Falkland Plateau is commonly regarded as a discrete microplate and is rotated into a position adjacent to the south-east coast of South Africa, which brings it within the range of the early Jurassic, Karoo(K)-Ferrar(F) mantle plume [reconstruction after Storey et al. (1996), position of plume head after White \& McKenzie (1989): AF Africa, AU Australia, EA East Antarctica, FP Falkland Plateau, NZ New Zealand, SA South America]; b) In post-Jurassic reconstructions the Falkland Plateau is commonly shown in continental continuity with South America [reconstruction after Nürnberg \& Müller (1991) and Turner et al. (1994) showing location of the early Cretaceous, Parana (P) and Etendeka (E) lavas, and the False Bay dyke swarm: CH Colorado-Hope transfer system, FA Falklands-Agulhas transfer system, FPB Falkland Plateau Basin, NFB North Falkland Basin]. Ma ages refer to ages of early Cretaceous magmatism in these locations 